\title{
Hematological Indices in Chronic Kidney Disease Patients and The Effect of Hemodialysis on These Indices
}

\author{
Alshabrawy.M.Abdelnabi, Emam Mohamed Mohamed Ismaeyl, Ahmed Mohamed Mohamed Abdellatif* \\ Internal Medicine Department, Faculty of Medicine, Zagazig University, Sharkia, Egypt. \\ *Corresponding Author: Ahmed Mohamed Mohamed Abdellatif, Email: elayan53@gmail.com
}

\begin{abstract}
Background: Chronic kidney disease (CKD) is a major health issue that affects people all over the globe. Hematological problems are connected to varying grades of CKD.

Objective: To study the relationship between chronic kidney disease and hematological indices, and to study the effect of hemodialysis on these parameters. Subjects and Methods: At Internal Medicine, Faculty of Medicine, Zagazig University, Sharkia, Egypt. we conducted this cross-sectional study in addition to the Nephrology Unit of El-Sahel teaching hospital from May 2019 to February 2020 on 165 subjects categorized into three groups with each group of 55 subjects. Group I included normal healthy persons. Group II involved chronic kidney disease patients not on hemodialysis (NDD-CKD) while Group III included patients on maintenance hemodialysis (DD-CKD). All participants' histories were gathered, with particular attention paid to demographic data and the co-morbid medical conditions as diabetes mellitus and hypertension. Full clinical examination was done including local and systemic examinations. In addition, a complete blood count, urea, and creatinine levels were measured.

Results: There is a significant association between CKD and changes in RBCs indices with a significant effect of hemodialysis on these changes. A decrease in the mean platelet count in diseased groups compared with normal ones was revealed. We also found differences between the 3 groups according to WBCs indices with significant changes between the 3 groups in TLC. Conclusion: CKD impacts all hematological parameters and hemodialysis also influence all these parameters.
\end{abstract}

Keywords: CKD, Anemia, Hemodialysis, Hematology.

\section{INTRODUCTION}

Many People from all around the world are affected by chronic kidney disease. Patients with ESRD use a significant number of healthcare services and have a higher rate of death, morbidity, and a lower standard of living than the general population. CKD is a term that refers to a group of primary disease pathologies resulting in functional or morphological renal defects, or even both, that lasts at least three months ${ }^{(\mathbf{1})}$.

Hematological problems are connected to varying grades of CKD. CKD patients are prone to anemia. Serious grades of anemia can impair the cardiac health in CKD patients, in addition to causing debilitating symptoms. Patients with lower $\mathrm{Hb}$ levels had a higher risk of cardiovascular complications and mortality and it can hasten the advancement of nondialysis CKD patients to end-stage renal disease (ESRD) ${ }^{(2)}$. There are also great changes in the hematological parameters in those patients as $\mathrm{Hb} \%$, RBC count, HCT, MCHC, RDW, MCV, or MCH. Total and differential white blood cell (WBC) counts are two other commonly impaired blood parameters in CKD that have yet to be completely characterized concerning $\mathrm{CKD}^{(3)}$. Platelet disorders have been discovered to be an important method for grading severity in CKD patients. MPV is a clear indicator for platelet activation due to inflammation, which is elevated in patients with CKD. When platelets are activated, they get bigger ${ }^{(4)}$.

The present study aimed to study the relationship between chronic kidney disease and hematological indices and to study the effect of hemodialysis on these parameters.

\section{SUBJECTS AND METHODS}

Technical design: Internal medicine and nephrology units at Zagazig University and the El-Sahel Teaching Hospital were used in this cross-sectional study from May 2019 to February 2020 on 165 subjects categorized into three groups with each group of 55 subjects. Group I included normal healthy persons. Group II involved chronic kidney disease patients not on hemodialysis (NDD-CKD) while Group III included patients on maintenance hemodialysis (DD-CKD).

Inclusion criteria: included patients of both sexes, aged more than 18 years, and known to have chronic kidney disease with documented increased renal profile more than 3 months ago.

Exclusion criteria: We excluded patients with a previous long-term systemic treatment with immunosuppressive drugs, major bleeding in the past three months, recent infection, primary known hematological disease, HIV infection, life-threatening malignancy, or current multiple myeloma. Pregnant or lactating women or patients who had a blood transfusion in the past 3 months were also excluded from the study.

Methods: A full history was taken from all participants with stress on the demographic data and the co-morbid medical conditions as diabetes mellitus and 
hypertension. Full clinical examination was done including local and systemic examinations. In addition, a complete blood count, urea, and creatinine levels were measured.

\section{Ethical Considerations:}

The study was authorized by the Institutional Research Board (IRB) of the Faculty of Medicine, Zagazig University after all subjects provided written informed permission following a clear explanation of the study. Code of Ethics of World Medical Association for studies involving humans (Declaration of Helsinki) has been adhered to in this research.

\section{Statistical Analysis}

IBM SPSS version 20.0 was used to analyze the data given into the computer (Armonk, NY: IBM Corp). Numbers and percentages were used to describe qualitative data. Distributions were tested using the Kolmogorov-Smirnov test to ensure they were normal Range (the difference between the minimum and maximum values), mean, standard deviation, and median were used to characterize quantitative data. The significance of the findings was assessed at a $5 \%$ level of significance. Chi-square test, Fisher's Exact, Student t-test, and Mann Whitney test were all employed in this study.

\section{RESULTS}

Table 1 shows a demographic comparison between the three groups analyzed. There are 28 males in 27 females in the control group with a mean age of 40.09 years compared with 28 males and 28 females with a mean age of 57.22 years in the NDD-CKD group and 26 males and 29 females with a mean age of 53.16 in the DDCKD group.

A comparison between the two studied groups $(2,3)$ according to risk factors is demonstrated in Table (2). $40 \%$ of the NDD-CKD group are diabetic (n 22) and $81.8 \%$ ( $\mathrm{n} \mathrm{45)}$ are hypertensive, and in the DD-CKD group $40 \%$ (n 22) are diabetic and $69.1 \%$ (n 38) are hypertensive.

Table (3) shows a comparison between the three studied groups according to RBCS indices. There is a significant association between CKD and changes in RBCs indices with a significant effect of hemodialysis on these changes. Mean hemoglobin and mean hematocrit are significantly decreased in CKD groups compared with control one. Mean MCV is decreased in CKD groups but still in the normal range. RBCs count is significantly decreased in CKD groups. $\mathrm{MCH}$ and $\mathrm{MCHC}$ are slightly affected by CKD. Mean RDW is significantly elevated in CKD groups.

Table 4 compares the platelets of the three groups that were examined. It shows a decrease in the mean platelet count in diseased groups compared to the normal one. It shows also that in CKD, mean MPV is decreased.

Table (5) demonstrates a comparison between the three studied groups according to the types of WBCs indices. It shows differences between the 3 groups according to WBCS indices with significant changes between the 3 groups in TLC. Although the percentage of the subpopulation of WBCs is similar between the 3 groups, absolute count varied significantly according to the variation in TLC. Comparing the three groups based on their renal function is shown in Table (6).

Table (1): Comparison between the demographic data of the three groups

\begin{tabular}{|c|c|c|c|c|c|c|c|c|}
\hline & \multicolumn{2}{|c|}{$\begin{array}{l}\text { Group I } \\
(\mathrm{n}=55)\end{array}$} & \multicolumn{2}{|c|}{$\begin{array}{c}\text { Group II } \\
(\mathrm{n}=55)\end{array}$} & \multicolumn{2}{|c|}{$\begin{array}{c}\text { Group III } \\
(\mathbf{n}=55)\end{array}$} & \multirow{2}{*}{$\begin{array}{c}\text { Test of } \\
\text { sig. }\end{array}$} & \multirow[t]{2}{*}{ p-value } \\
\hline & No. & $\%$ & No. & $\%$ & No. & $\%$ & & \\
\hline \multicolumn{9}{|l|}{ Gender } \\
\hline Male & 28 & 50.9 & 27 & 49.1 & 26 & 47.3 & \multirow{2}{*}{$\begin{array}{c}\chi^{2}= \\
0.146\end{array}$} & \multirow{2}{*}{0.930} \\
\hline Female & 27 & 49.1 & 28 & 50.9 & 29 & 52.7 & & \\
\hline \multicolumn{9}{|l|}{ Age (years) } \\
\hline Min. - Max. & \multicolumn{2}{|c|}{$22.0-80.0$} & \multicolumn{2}{|c|}{$22.0-81.0$} & \multicolumn{2}{|c|}{$23.0-76.0$} & \multirow{3}{*}{$\begin{array}{c}\mathrm{F}= \\
1.355\end{array}$} & \multirow{3}{*}{0.261} \\
\hline Mean \pm SD & \multicolumn{2}{|c|}{$54.09 \pm 14.82$} & \multicolumn{2}{|c|}{$57.22 \pm 12.61$} & \multicolumn{2}{|c|}{$53.16 \pm 13.08$} & & \\
\hline Median (IQR) & \multicolumn{2}{|c|}{$\begin{array}{c}54.0 \\
(42.0-65.50)\end{array}$} & \multicolumn{2}{|c|}{$\begin{array}{c}59.0 \\
(52.0-65.0)\end{array}$} & \multicolumn{2}{|c|}{$\begin{array}{c}55.0 \\
(44.0-62.5)\end{array}$} & & \\
\hline
\end{tabular}

$\chi^{2}$ : Chi-square test

F: F for ANOVA test

p: p-value for comparing between the studied groups.

Table (2): Comparison between the two studied groups according to risk factors

\begin{tabular}{|l|c|c|c|c|c|c|}
\hline \multirow{3}{*}{ Risk factors } & \multicolumn{2}{|c|}{$\begin{array}{c}\text { Group II } \\
(\mathbf{n = 5 5})\end{array}$} & \multicolumn{2}{c|}{$\begin{array}{c}\text { Group III } \\
(\mathbf{n = 5 5})\end{array}$} & \multirow{2}{*}{$\begin{array}{c}\text { Test of } \\
\text { Sig. }\end{array}$} & \multirow{2}{*}{ p-value } \\
\cline { 2 - 5 } & No. & \% & No. & \% & & \\
\hline DM & 22 & 40.0 & 22 & 40.0 & 0.00 & 1.000 \\
\hline HTN & 45 & 81.8 & 38 & 69.1 & 2.405 & 0.121 \\
\hline
\end{tabular}


Table (3): Comparison between the RBCs indicators of the three groups

\begin{tabular}{|c|c|c|c|c|c|}
\hline CBC & $\begin{array}{l}\text { Group I } \\
(n=55)\end{array}$ & $\begin{array}{c}\text { Group II } \\
(\mathrm{n}=55)\end{array}$ & $\begin{array}{c}\text { Group III } \\
(n=55)\end{array}$ & $\begin{array}{l}\text { Test of } \\
\text { sig. }\end{array}$ & p-value \\
\hline \multicolumn{6}{|c|}{ Hemoglobin g/dL } \\
\hline Mean \pm SD. & $12.42 \pm 0.97$ & $10.30 \pm 1.53$ & $10.28 \pm 1.58$ & \multirow[b]{2}{*}{$\begin{array}{c}\mathrm{F}= \\
43.297^{*}\end{array}$} & \multirow[b]{2}{*}{$<0.001^{*}$} \\
\hline Median (IQR) & $\begin{array}{c}12.10 \\
(11.7-13.4)\end{array}$ & $\begin{array}{c}10.10 \\
(9.5-11.0)\end{array}$ & $\begin{array}{c}10.20 \\
(9.1-11.1)\end{array}$ & & \\
\hline Sig. bet. grps. & \multicolumn{3}{|c|}{$\mathrm{p}_{1}<0.001^{*}, \mathrm{p}_{2}<0.001^{*}, \mathrm{p}_{3}=0.996$} & & \\
\hline \multicolumn{6}{|l|}{ Hematocrit \% } \\
\hline Mean \pm SD. & $38.86 \pm 3.47$ & $31.20 \pm 5.0$ & $31.79 \pm 4.58$ & \multirow[b]{2}{*}{$\begin{array}{c}\mathrm{F}= \\
51.703^{*}\end{array}$} & \multirow[b]{2}{*}{$<0.001^{*}$} \\
\hline Median (IQR) & $\begin{array}{c}37.80 \\
(36.0-41.9)\end{array}$ & $\begin{array}{c}30.30 \\
(27.7-34.0)\end{array}$ & $\begin{array}{c}31.30 \\
(29.4-34.3)\end{array}$ & & \\
\hline Sig. bet. grps. & \multicolumn{3}{|c|}{$\mathrm{p}_{1}<0.001^{*}, \mathrm{p}_{2}<0.001^{*}, \mathrm{p}_{3}=0.759$} & & \\
\hline \multicolumn{6}{|l|}{ MCV fl } \\
\hline Mean \pm SD. & $90.49 \pm 1.71$ & $83.14 \pm 7.92$ & $85.18 \pm 7.71$ & \multirow[b]{2}{*}{$\begin{array}{c}\mathrm{H}= \\
34.811^{*}\end{array}$} & \multirow[b]{2}{*}{$<0.001^{*}$} \\
\hline Median (IQR) & $\begin{array}{c}90.80 \\
(89.6-910.60)\end{array}$ & $\begin{array}{c}82.10 \\
(77.9-88.3)\end{array}$ & $\begin{array}{c}86.0 \\
(80.6-91.4)\end{array}$ & & \\
\hline Sig. bet. grps. & \multicolumn{3}{|c|}{$\mathrm{p}_{1}<0.001^{*}, \mathrm{p}_{2}<0.001^{*}, \mathrm{p}_{3}=0.133$} & & \\
\hline \multicolumn{6}{|c|}{ RBCS count $\left(\mathrm{x10}^{\wedge} \mathbf{6}\right) / \mathrm{ul}$} \\
\hline Mean \pm SD. & $4.42 \pm 0.82$ & $3.77 \pm 0.60$ & $3.75 \pm 0.55$ & \multirow[b]{2}{*}{$\begin{array}{c}\mathrm{F}= \\
18.103^{*}\end{array}$} & \multirow[b]{2}{*}{$<0.001^{*}$} \\
\hline Median (IQR) & $\begin{array}{c}4.13 \\
(3.9-4.9)\end{array}$ & $\begin{array}{c}3.74 \\
(3.5-4.1)\end{array}$ & $\begin{array}{c}3.68 \\
(3.3-4.2)\end{array}$ & & \\
\hline Sig. bet. grps. & \multicolumn{3}{|c|}{$\mathrm{p}_{1}<0.001^{*} \mathrm{p}_{2}<0.001^{*}, \mathrm{p}_{3}=0.984$} & & \\
\hline \multicolumn{6}{|l|}{ MCH pg-cell } \\
\hline Mean \pm SD. & $28.85 \pm 0.56$ & $27.45 \pm 2.65$ & $27.55 \pm 2.88$ & \multirow{2}{*}{$\begin{array}{c}\mathrm{F}= \\
6.509^{*}\end{array}$} & \multirow[b]{2}{*}{$0.002^{*}$} \\
\hline Median (IQR) & $\begin{array}{c}28.90 \\
(28.5-29.2)\end{array}$ & $\begin{array}{c}27.60 \\
(25.6-29.3)\end{array}$ & $\begin{array}{c}27.40 \\
(25.7-29.5)\end{array}$ & & \\
\hline Sig. bet. grps. & \multicolumn{3}{|c|}{$p_{1}=0.004^{*}, p_{2}=0.009^{*}, p_{3}=0.969$} & & \\
\hline \multicolumn{6}{|l|}{ MCHC (g/dl) } \\
\hline Mean \pm SD. & $31.85 \pm 0.60$ & $33.07 \pm 1.73$ & $32.37 \pm 2.07$ & \multirow[b]{2}{*}{$\begin{array}{c}F= \\
8.009\end{array}$} & \multirow[b]{2}{*}{$<0.001^{*}$} \\
\hline Median (IQR) & $\begin{array}{c}31.80 \\
(31.4-32.3)\end{array}$ & $\begin{array}{c}33.20 \\
(31.9-34.6)\end{array}$ & $\begin{array}{c}32.20 \\
(30.6-33.9)\end{array}$ & & \\
\hline Sig. bet. grps. & \multicolumn{3}{|c|}{$p_{1}<0.001^{*}, p_{2}=0.212, p_{3}=0.059$} & & \\
\hline \multicolumn{6}{|l|}{ RDW-CV \% } \\
\hline Mean \pm SD. & $13.44 \pm 0.85$ & $15.25 \pm 2.20$ & $15.08 \pm 1.82$ & \multirow{3}{*}{$\begin{array}{c}\mathrm{F}= \\
18.523^{*}\end{array}$} & \multirow[b]{2}{*}{$<0.001^{*}$} \\
\hline Median (IQR) & $\begin{array}{c}13.70 \\
(12.8-13.9)\end{array}$ & $\begin{array}{c}14.80 \\
(13.9-16.5)\end{array}$ & $\begin{array}{c}14.50 \\
(14.0-16.1)\end{array}$ & & \\
\hline Sig. bet. grps. & \multicolumn{3}{|c|}{$p_{1}<0.001^{*}, p_{2}<0.001^{*}, p_{3}=0.64$} & & \\
\hline
\end{tabular}

Table (4): Comparison between the platelets in the three groups.

\begin{tabular}{|c|c|c|c|c|c|}
\hline & $\begin{array}{l}\text { Group I } \\
(\mathrm{n}=55)\end{array}$ & $\begin{array}{c}\text { Group II } \\
(\mathrm{n}=55)\end{array}$ & $\begin{array}{c}\text { Group III } \\
(n=55)\end{array}$ & $\mathbf{F}$ & p-value \\
\hline \multicolumn{6}{|c|}{ Platelet count $\left(\mathrm{x}^{10^{\wedge}}\right) / \mu \mathrm{l}$} \\
\hline Mean \pm SD. & $255.2 \pm 54.32$ & $220.1 \pm 34.60$ & $234.9 \pm 39.0$ & \multirow[b]{2}{*}{$3.224^{*}$} & \multirow[b]{2}{*}{$0.042^{*}$} \\
\hline Median (IQR) & $\begin{array}{c}255.0 \\
(209-293.5)\end{array}$ & $\begin{array}{c}199.0 \\
(165-272)\end{array}$ & $\begin{array}{c}226.0 \\
(183-280)\end{array}$ & & \\
\hline Sig. bet. grps. & \multicolumn{3}{|c|}{$p_{1}=0.031^{*}, p_{2}=0.287, p_{3}=0.0553$} & & \\
\hline \multicolumn{6}{|l|}{ MPV fl } \\
\hline Mean \pm SD. & $10.03 \pm 1.36$ & $9.27 \pm 1.65$ & $9.09 \pm 1.61$ & \multirow[b]{2}{*}{$5.823^{*}$} & \multirow[b]{2}{*}{$0.004^{*}$} \\
\hline Median (IQR) & $\begin{array}{c}10.10 \\
(9.20-10.60)\end{array}$ & $\begin{array}{c}9.0 \\
(8.36-10.01)\end{array}$ & $\begin{array}{c}8.94 \\
(8.20-9.70)\end{array}$ & & \\
\hline Sig. bet. grps. & \multicolumn{3}{|c|}{$p_{1}=0.027^{*}, p_{2}=0.004^{*}, p_{3}=0.814$} & & \\
\hline
\end{tabular}


Table (5): Comparison of WBC indices among the three groups

\begin{tabular}{|c|c|c|c|c|c|}
\hline Types of WBCs & $\begin{array}{l}\text { Group I } \\
(n=55)\end{array}$ & $\begin{array}{c}\text { Group II } \\
(n=55)\end{array}$ & $\begin{array}{c}\text { Group III } \\
(n=55)\end{array}$ & $\begin{array}{l}\text { Test of } \\
\text { sig. }\end{array}$ & p-value \\
\hline \multicolumn{6}{|l|}{$\operatorname{TLC}(\mathbf{x 1 0} 3) / \mathrm{ul}$} \\
\hline Mean \pm SD. & $6.51 \pm 1.06$ & $7.64 \pm 2.03$ & $7.28 \pm 2.09$ & \multirow[b]{2}{*}{$\begin{array}{c}\mathrm{F}= \\
5.730^{*}\end{array}$} & \multirow[b]{2}{*}{$0.004^{*}$} \\
\hline Median (IQR) & $\begin{array}{c}6.80 \\
(5.8-7.1)\end{array}$ & $\begin{array}{c}7.60 \\
(6.3-9.5)\end{array}$ & $\begin{array}{c}7.30 \\
(5.4-8.6)\end{array}$ & & \\
\hline Sig. bet. grps. & \multicolumn{3}{|c|}{$p_{1}=0.003^{*}, p_{2}=0.067, p_{3}=0.534$} & & \\
\hline \multicolumn{6}{|l|}{ Basophils (\%) } \\
\hline Mean \pm SD. & $0.56 \pm 0.50$ & $0.29 \pm 0.41$ & $0.15 \pm 0.36$ & \multirow{3}{*}{$\begin{array}{c}\mathrm{H}= \\
22.518^{*}\end{array}$} & \multirow[b]{2}{*}{$<0.001^{*}$} \\
\hline Median (IQR) & $\begin{array}{c}1.0 \\
(0.0-1.0)\end{array}$ & $\begin{array}{c}0.0 \\
(0.0-0.6)\end{array}$ & 0.0 & & \\
\hline Sig. bet. grps. & \multicolumn{3}{|c|}{$\mathrm{p}_{1}=0.007^{*}, \mathrm{p}_{2}<0.001^{*}, \mathrm{p}_{3}=0.042^{*}$} & & \\
\hline \multicolumn{6}{|l|}{ Eosinophils (\%) } \\
\hline Mean \pm SD. & $2.0 \pm 0.01$ & $3.15 \pm 0.37$ & $4.56 \pm 0.78$ & \multirow{2}{*}{$\begin{array}{c}H= \\
27.201^{*}\end{array}$} & \multirow[b]{2}{*}{$<0.001^{*}$} \\
\hline Median (IQR) & 2.0 & $\begin{array}{c}2.30 \\
(1.8-4.0) \\
\end{array}$ & $\begin{array}{c}3.0 \\
(2.0-6.0)\end{array}$ & & \\
\hline Sig. bet. grps. & \multicolumn{3}{|c|}{$p_{1}=0.004^{*}, p_{2}<0.001^{*}, p_{3}=0.022^{*}$} & & \\
\hline \multicolumn{6}{|l|}{ Neutrophils (\%) } \\
\hline Mean \pm SD. & $62.67 \pm 3.50$ & $65.01 \pm 8.59$ & $60.73 \pm 7.85$ & \multirow[b]{2}{*}{$\begin{array}{c}\mathrm{F}= \\
5.128^{*}\end{array}$} & \multirow[b]{2}{*}{$0.007^{*}$} \\
\hline Median (IQR) & $\begin{array}{c}62.0 \\
(61.0-64.0)\end{array}$ & $\begin{array}{c}64.80 \\
(60.0-70.0)\end{array}$ & $\begin{array}{c}60.0 \\
(55.0-66.0)\end{array}$ & & \\
\hline Sig. bet. grps. & \multicolumn{3}{|c|}{$p_{1}=0.192, p_{2}=0.316, p_{3}=0.005^{*}$} & & \\
\hline \multicolumn{6}{|l|}{ Lymphocytes (\%) } \\
\hline Mean \pm SD. & $29.98 \pm 3.11$ & $26.20 \pm 7.87$ & $29.16 \pm 7.35$ & \multirow[b]{2}{*}{$\begin{array}{c}\mathrm{F}= \\
5.209^{*}\end{array}$} & \multirow[b]{2}{*}{$0.006^{*}$} \\
\hline Median (IQR) & $\begin{array}{c}31.0 \\
(29.0-32.0)\end{array}$ & $\begin{array}{c}25.40 \\
(22.0-30.5)\end{array}$ & $\begin{array}{c}28.0 \\
(25.0-35.0)\end{array}$ & & \\
\hline Sig. bet. grps. & \multicolumn{3}{|c|}{$p_{1}=0.007^{*}, p_{2}=0.785, p_{3}=0.045^{*}$} & & \\
\hline \multicolumn{6}{|l|}{ Monocytes (\%) } \\
\hline Mean \pm SD. & $4.73 \pm 1.18$ & $5.16 \pm 1.85$ & $5.33 \pm 1.82$ & \multirow[b]{2}{*}{$\begin{array}{c}\mathrm{F}= \\
1.961\end{array}$} & \multirow[b]{2}{*}{0.144} \\
\hline Median (IQR) & $\begin{array}{c}4.0 \\
(4.0-5.0) \\
\end{array}$ & $\begin{array}{c}5.0 \\
(4.0-6.15) \\
\end{array}$ & $\begin{array}{c}5.0 \\
(4.0-6.50) \\
\end{array}$ & & \\
\hline
\end{tabular}

Table (6): Comparison of renal functions between the three groups

\begin{tabular}{|c|c|c|c|c|c|}
\hline Renal function & $\begin{array}{l}\begin{array}{l}\text { Group I } \\
(n=55)\end{array} \\
\end{array}$ & $\begin{array}{c}\text { Group II } \\
(n=55)\end{array}$ & $\begin{array}{c}\text { Group III } \\
(\mathbf{n}=55)\end{array}$ & $\mathbf{F}$ & p-value \\
\hline \multicolumn{6}{|l|}{ Urea (pre) mg/dl } \\
\hline Mean \pm SD & $27.89 \pm 4.96$ & $112.3 \pm 4.53$ & $150.4 \pm 8.06$ & \multirow{2}{*}{$323.607^{*}$} & \multirow{2}{*}{$<0.001^{*}$} \\
\hline Median (IQR) & $\begin{array}{c}28.0 \\
(24.0-30.50)\end{array}$ & $\begin{array}{c}107.0 \\
(92.0-134.5)\end{array}$ & $\begin{array}{c}153.0 \\
(133.0-166.0)\end{array}$ & & \\
\hline Sig. bet. grps. & \multicolumn{3}{|c|}{$\mathrm{p}_{1}<0.001^{*}, \mathrm{p}_{2}<0.001^{*}, \mathrm{p}_{3}<0.001^{*}$} & & \\
\hline \multicolumn{6}{|l|}{ Creatinine mg/dl } \\
\hline Mean \pm SD. & $0.85 \pm 0.11$ & $3.19 \pm 0.36$ & $10.25 \pm 2.51$ & \multirow[b]{2}{*}{$485.705^{*}$} & \multirow[b]{2}{*}{$<0.001^{*}$} \\
\hline Median (IQR) & $\begin{array}{c}0.82 \\
(0.78-0.90)\end{array}$ & $\begin{array}{c}2.96 \\
(2.1-4.0)\end{array}$ & $\begin{array}{c}10.10 \\
(8.2-12.3)\end{array}$ & & \\
\hline Sig. bet. grps. & \multicolumn{3}{|c|}{$\mathrm{p}_{1}<0.001^{*}, \mathrm{p}_{2}<0.001^{*}, \mathrm{p}_{3}<0.001^{*}$} & & \\
\hline
\end{tabular}

F: F for ANOVA test, Pairwise comparison bet. each 2 groups was done using Post Hoc Test, (Tukey) 


\section{DISCUSSION}

CKD is related to several hematological abnormalities affecting all types of blood cells. As CKD advances, anemia becomes more prominent, and it is linked to several cardiac disorders. In addition, CKD usually causes platelet disorders and primary hemostasis impairment ${ }^{(5)}$.

Our study is designed to study the hematological indices in chronic kidney disease patients divided into two groups; a group of patients with CKD not on hemodialysis (NDD-CKD) and another group undergoing regular hemodialysis (DD-CKD). The two groups are studied in comparison with a control group.

Regarding RBCS indices, our study demonstrates that anemia is a major health problem in the two CKD groups. The mean hemoglobin concentration in the NDD-CKD group was $10.3 \mathrm{~g} / \mathrm{dl}$, and in the DD-CKD group was $10.82 \mathrm{~g} / \mathrm{dl}$ using pre-dialysis blood samples, compared to $12.42 \mathrm{~g} / \mathrm{dl}$ in normal healthy individuals. These differences were statistically significant. These results are consistent with other studies as Yasir and colleagues had found that there was normocytic normochromic anemia in $(87,4 \%)$ of hemodialysis patients. This slight difference between this study and ours in the prevalence of anemia is because the previous study used a hemoglobin concentration below $11 \mathrm{~g} / \mathrm{dl}$ to define anemia ${ }^{(\mathbf{6})}$.

Another study conducted in 2020 had found that the mean hemoglobin concentration in DD-CKD patients was $8.6 \mathrm{~g} / \mathrm{dl}$ in pre-dialysis collected samples (7).

We found that hematocrit in the NDD-CKD group was ranging from $20.80-47.50 \%$ with a mean value of $31.2 \%$. And in DD-CKD group was ranging from $20.60-44.30 \%$ with a mean of $31.79 \%$, compared to the mean hematocrit of $38.86 \%$ in the control healthy group. The mean red blood cell count in the NDDCKD group was 3.77 million cells/ $\mu 1$, and 3.75 million cells/ul in the DD-CKD group compared to 4.42 million cells/ $\mu 1$ in the control healthy group. These results are like those of Alghythan and Alsaeed in 2012 who had found in a group of 100 patients on hemodialysis that the mean hematocrit in this study was $35.14 \%$, and the mean RBCs count in this study was 4.13 million cells/ $\mu 1^{(8)}$.

Regarding mean corpuscular volume $\mathrm{MCV}$, we found that the MCV mean value in the NDD-CKD group is $83.14 \mathrm{fl}$, and in the DD-CKD group is 85.18 fl compared with a mean MCV value of $90.49 \mathrm{fl}$ in the control healthy group. This shows that normocytic anemia is the most prevalent type in our patients which is consistent with other studies ${ }^{(7)}$.

Mean corpuscular hemoglobin MCH shows slight variations between the 3 groups, with a mean value of 27.45 and 27.55 picograms/cell in group NDD-CKD and DD-CKD group respectively, compared with
28.58 picograms/cell in the control group. However, mean corpuscular hemoglobin concentration MCHC values are similar between the three groups with a mean value of 33.07 and $32.37 \mathrm{~g} / \mathrm{dl}$ in the NDD-CKD group and DD-CKD group respectively, with a mean value of $31.58 \mathrm{~g} / \mathrm{dl}$ in the control healthy group. This supports the finding that renal anemia is also of normochromic type. Hsieh and colleagues discovered a median MCV level of $90.8 \mathrm{fl}$ in a retrospective observational cohort study of 1439 patients in stages $3-5 \mathrm{CKD}^{(9)}$.

We also found that CKD (being dialysisdependent or not), was associated with increased red cell distribution width (RDW). In CKD group 2, RDW-CV was increased with a mean value of $15.25 \%$. In HD group 3, this value was $15.08 \%$, compared with $13.44 \%$ in the control healthy group. In their study on 80 CKD patients undergoing hemodialysis, Hirotaka and colleagues found that the mean value of RDW was $14.9 \%{ }^{(10)}$.

Regarding platelets indices, we found that most CKD patients in both groups had a normal platelet count. The mean values of platelet count were 220.09 $\mathrm{x} 103 / \mu 1$ and $234.9 \times 103 / \mu \mathrm{l}$ in the NDD-CKD group and DD-CKD group respectively, compared with a slightly higher mean value of $255.2 \times 103 / \mu 1$ in the control group, meaning that thrombopoiesis is not as affected as erythropoiesis. This is consistent with the results of a study conducted by Iyawe and Adejumo in 2018 on 100 CKD dialysis-dependent patients as they found that the pre-dialysis mean value of platelet count was $200.79 \times 103 / \mu l$ which elevated to 219.18 $\mathrm{x} 103 / \mu 1$ post-dialysis ${ }^{(11)}$.

Mean platelet volume MPV was also decreased in CKD patients in our study. With a mean value of 9.27 $\mathrm{fl}$ in the NDD-CKD group and $9.09 \mathrm{fl}$ in the DD-CKD group compared with $10.03 \mathrm{fl}$ in control group 1 . The difference between the control group and each of the diseased groups was significant, while it was nonsignificant between the diseased groups. Bilen and colleagues in 2014 also noted that the mean value of MPV was decreased in CKD patients. This mean value was $7.97 \mathrm{fl}$ and $7.92 \mathrm{fl}$ in NDD-CKD and DDCKD patients, respectively ${ }^{(\mathbf{1 2})}$.

Lastly, we observed that the total count and subpopulation of white blood cells are also affected. The mean TLC was $7.64 \times 103 / \mu 1$ and $7.28 \times 103 / \mu 1$ for the NDD CKD group and DD CKD group respectively, compared with a mean value of 6.5 $\mathrm{x} 103 / \mu 1$ for TLC in the normal control group which may reflect a state of subclinical chronic inflammation in CKD. In their study on hematological indices in hemodialysis patients, Habib and colleagues also observed an increase in the mean TLC from $5.7 \times 103 / \mu 1$ in the control group to $6.06 \mathrm{x} 103 / \mu \mathrm{l}$ in a pre-dialysis sample of $\mathrm{HD}$ patients ${ }^{(13)}$. 


\section{CONCLUSION AND RECOMMENDATIONS}

We concluded that CKD impacts not just RBCS measurements, while all other hematological parameters as well, and hemodialysis also influences all these parameters. It is necessary to maintain sufficient hemodialysis to promote good hematological parameters. We recommend the use of all blood indices in the continuous assessment of CKD patients.

Financial support and sponsorship: Nil.

Conflict of interest: Nil.

\section{REFERENCES}

1. Romagnani $\mathbf{P}$, Remuzzi G, Glassock $\mathbf{R}$ et al. (2017): Chronic kidney disease. Nat rev Dis Prim., $3(1): 1-24$.

2. Stirnadel H, Luo J, Kler L et al. (2018): Anemia and mortality in patients with nondialysis-dependent chronic kidney disease. BMC Nephrol., 19(1):1-1.

3. George C, Matsha T, Erasmus $\mathrm{R}$ et al. (2018): Haematological profile of chronic kidney disease in a mixed-ancestry South African population: a crosssectional study. BMJ Open, 8(11): 25694-99.

4. Aziz A, Saad A, Bazeed M et al. (2018): A comparative study of platelet parameters in chronic kidney disease, end-stage renal disease patients undergoing hemodialysis and healthy individuals. Egypt J Hosp Med., 71(6):3429-33.

5. Vanbladel E, Dejager R, Walter D et al. (2012): Platelets of patients with chronic kidney disease demonstrate deficient platelet reactivity in vitro. BMC Nephrol., 13(1):1-6.

6. Hakim Y, Abbas A, Khalil A et al. (2016): The effect of hemodialysis on hemoglobin concentration, platelets count and white blood cells count in endstage renal failure. Int J Med Sci Pub Heal., 5(5):2235 .

7. Kesarkhane M, Haravi R, Kittur S et al. (2020): Study of Hematological Parameters in End-Stage Renal Disease Patients; Those on Regular Hemodialysis as Renal Replacement Therapy. Saudi J Pathol Microbiol., 10(36):348-53.

8. Alghythan A, Alsaeed A (2012): Hematological changes before and after hemodialysis. Sci Res Ess., 7(4):490-7.

9. Hsieh Y, Chang C, Kor $\mathrm{C}$ et al. (2017): Mean corpuscular volume and mortality in patients with CKD. Clin J Am Soc Nephrol., 12(2):237-44.

10. Fukasawa H, Ishibuchi K, Kaneko M et al. (2017): Red Blood Cell Distribution Width Is Associated With All-Cause and Cardiovascular Mortality in Hemodialysis Patients. Ther Apher Dial., 21(6): 56571.

11. Iyawe I, Adejumo O (2018): Hematological profile of predialysis chronic kidney disease patients in a tertiary hospital in Southern Nigeria. J Med Trop., 20(1):36-42.

12. Bilen Y, Cankaya E, Keles M et al. (2014): Does decreased mean platelet volume predict inflammation in chronic renal failure, dialysis, and transplanted patients?. Ren fail., 36(1):69-72.

13. Habib A, Ahmad R, Rehman S (2017): Hematological changes in patients of chronic renal failure and the effect of hemodialysis on these parameters. Int J Res Med Sci., 5(11):4998-5003. 